\title{
CHARACTERISTICS OF VISIBLE AUTUMN MIGRATIONS OF THE DUNNOCK PRUNELLA MODULARIS (LINNAEUS, 1758) IN NATIONAL PARK "PRYPIAT-STOKHID” IN 2012-2017
}

\section{Khymyn}

The aim. The main purpose of the study was to find out the peculiarities of autumn migrations of birds, in particular such little-studied species as the Dunnock. This is necessary for the development and implementation of a management plan in the National Park for a whole complexes of migratory birds and separate species, first of all rare or small in number quantity.

Materials and methods. Our research was conducted at the Prypiat River near Svalovychi village in Liubeshiv district, Volyn region of Ukraine in September and October 2012-2017. Observations were performed visually, starting in the morning half an hour before sunrise and ending in the evening half an hour after sunset (all hours of the light part of a day, without interruption). The light part of a day was divided into hour of observations, taking into the daily changes of sunrise and sunset. Flight altitude was determined visually, and flight directions - by 8 rhumbs.

Results. There were 2124 individuals of the Dunnock counted during the study of visible autumn migration birds at one observation point in 2012-2017. The most bird migrated in flocks, but a significant part of them flew alone. The most numerous migrants this species were in small flocks - 2-5 individuals $89.9 \%$ of all counted birds in flocks). There are from 2 to 38 individuals in one flock, on average $-3.2 \pm 0.15$ individuals. The main passage lasted from the 2nd decade of September to the middle of the 2nd decade of October. The majority of them flew in the morning, in the first 3 hours of observations (75.5-83.5\% of all counted birds in different years, in average $79.6 \%)$. The majority birds of this species were observed in flight within altitudes between 30 and $40 \mathrm{~m}(59.4 \%)$ and the predominant direction of flight was $W(52.4 \%)$ and some less - SW (45.4\%).

Conclusions. According to the results of 6-years research, the peculiarities of visible autumn migrations of the Dunnock have been clarified (the main passage - the 2nd decade of September - middle of the 2nd decade of October, majority of birds flew in the first 3 hours of observations, used altitudes between 30 and $40 \mathrm{~m}$ and the $W$ and $S W$ directions of passage). The results of our research are the basis for the further study of this species, planning and implementation of conservation measures for birds in the National Park "Prypiat-Stokhid". The obtained data are also a supplement to the state of study of this species in Ukraine

Keywords: birds, Dunnock, visible autumn migrations, characteristics, National Park "Prypiat-Stokhid"

Copyright $(\mathrm{C}$ 2020, M. Khymyn.

This is an open access article under the CC BY license (http://creativecommons.org/licenses/by/4.0).

\section{Introduction}

There are Dunnock Prunella modularis (Linnaeus, 1758) nests in the Carpathians and the Crimean Mountains mainly, occasionally in the northern region of Ukrainian Polissia [1]. This species is possibly breeding (breeding not confirmed) and was considered rare during migrations in National Park "Prypiat-Stokhid". The Dunnock is little-studies species of bird not only our National Park or West Polissia region, but also in Ukraine in general. Only single birds were observed during breeding season and not annually in National Park. Therefore, the main information about this species was collected during the migration period, in particular during the study of visible autumn migrations of birds.

This information is necessary for the development and implementation of a management plan in the National Park for a whole complexes of migratory birds and separate species, first of all rare or few numerous.

\section{Literature review}

The Dunnock is rare breeding, few numerous migratory and smaller-studied bird species in the National
Park "Prypiat-Stokhid" and the NW of Ukraine generally. There were no publications about autumn migrations of this species and other bird species from the territory of this National Park before its creation in 2007. The study of visible autumn migration of birds in the National Park began in 2012 and lasted 6 years. The first results of our study of visible autumn migrations of birds in National Park were published in 2014 [2] and last - in 2017 [3]. These publications provide annual data and peculiarities of autumn migrations of birds (analysis by bird orders and some families and species, its counts, observation hours, height and direction of the passage). Migrations of this species have been studied by different researches in Ukraine but they mostly concerned the phenology of migrations [4, 5]. In recent years, not only migrations of birds are studied (time, directions and height of passage $[6,7]$, morphometric data of birds [8], change of bird plumage during migration and identification of it age) [9] and biometrical differentiation [10], but also applied directions of research of migratory birds are being developed. Thus, in particular, studies are conducted related to the influence of wind power plant $[11,12]$ or possible 
impact due to possibility of its construction on migratory birds [13] and influence of geomagnetic field on migratory activity of birds [14]. Migrations of the Dunnock as well as other species of birds have certain peculiarities (beginning and ending of the passage, intensity, height and direction of migration) in a separate area. Therefore, their study is important for the development and implementation of measures to protect their migration ways in national parks and other protected area.

\section{The aim and objectives of the research}

The aim of the research is to study the peculiarities of visible autumn migrations of the Dunnock, to determine the importance of the area for the protection of its migration ways and to supplement the data on the study of the species.

To achieve this aim, the following objectives are identified and solved:

1) to find out the main peculiarities of visible autumn migrations (dynamics of flight during the light part of the day, altitude and direction);

2) estimate the number of migratory birds and distribution of birds in migratory flocks; species

3 ) determine the main period of migration of this

\section{Materials and methods of the research}

The research were conducted on the territory of National Park "Prypiat-Stokhid" at left (northern) bank of the Prypiat River near Svalovychi village in Liubeshiv district, Volyn region of Ukraine (N 51 $52^{\prime}$ E 25 39') during the part of September until the beginning of the end of 2nd decade of October 2012-2017. The number of observation days varied in different years: 4-12.IX, 22.IX-20.2012， 09.IX-10.X.2013， 22.IX-19.X.2014, 21.IX-20.X.2015, 19.IX-19.X.2016 i 18.IX-17.X.2017.

Visible autumn migrations were studied according to conventional method $[15,16]$ with some of our changes and additions [2, 3, 17-19]. Migratory birds were observed visually, starting in the morning half an hour before sunrise and ending in the evening half hour after sunset (all hours of the light part of a day, without interruption). The width of the accounting corridor for these birds was $200 \mathrm{~m}$ ( $100 \mathrm{~m}$ to the left and right of the observation point). The light part of a day was divided into hour of observations (morning and day observation hours - No. 1-11 and evening observation hours - No. 2 and No. 1), taking into the daily changes of sunrise and sunset (observation time decreased daily by 1,5-2 min). All observation hours were complete (a full hour), except last before evening hour (No. 11 - on beginning observations in the September and No. 10 - on ending observations in the October) which was incomplete (less or more than 1 hour). Flight altitude was determined visually, and flight directions - by 8 rhumbs, taking into account the experience of other researchers [16]. All data on the number of account birds of each species, altitude and direction on their flight during the observation hour were recorded in a notebook. Species were determined visually and by voice. The binoculars were used during observations of migratory birds. The photographing was sometimes used to count the number of birds in large flocks and to identify species. In addition, the time of precipitation and wind directions were registered in observation hours. The weather data from the Liubeshiv meteorological station was used and analysed [2, 3, 17-19].

A total of 1980 hours were spent on studying of visible autumn migrations of birds in 2012-2017 at a stationary point near Svalovychi village in National Park "Prypiat-Stokhid".

Calculation and verification of data were performed in the program Microsoft Office Excel 2003. Used the conventional methods of statistical data processing - determined the error of the mean with an accuracy of $0,01[20]$.

\section{Research results}

There were 2124 individuals of the Dunnock counted during the study of visible autumn migration of birds in 2012-2017 (Table 1).

There were different numbers of migratory birds in different years (the most was counted in 2014 and the least in 2013). The most bird migrated in flocks, but a significant part of them flew alone (Table 1), which is typical for this species [21]. For the analysis of autumn migrations of the Dunnock, the total of birds counted for 2012-2017 was used.

The distribution of the number of birds in flocks during visible autumn migrations in 2012-2017 is shown in Table 2 .

Table 1

Number of the Dunnock counted during visible autumn migrations near the Svalovychi village in 2012-2017

\begin{tabular}{|c|c|c|c|c|c|c|c|}
\hline \multirow{2}{*}{ Indexes } & \multicolumn{6}{|c|}{ Year } & \multirow{2}{*}{ Total } \\
\hline & 2012 & 2013 & 2014 & 2015 & 2016 & 2017 & \\
\hline Individuals & 329 & 270 & 591 & 249 & 387 & 298 & 2124 \\
\hline Birds in flocks $(\%)$ & 58.7 & 54.1 & 60.9 & 53.8 & 71.3 & 72.2 & 62.3 \\
\hline Single birds $(\%)$ & 41.3 & 45.9 & 39.1 & 46.2 & 28.7 & 27.8 & 37.7 \\
\hline
\end{tabular}


Table 2

Distribution of the number of individuals in Dunnock's flocks on autumn passage in 2012-2017

\begin{tabular}{|c|c|c|c|c|c|c|c|}
\hline \multirow[b]{2}{*}{ Year } & \multicolumn{5}{|c|}{ Flock size (number of flocks / birds), $\%$} & \multirow{2}{*}{$\begin{array}{c}\text { Total of } \\
\text { flocks / birds } \\
\text { in flocks }\end{array}$} & \multirow{2}{*}{$\begin{array}{l}\text { Average number of } \\
\text { birds in flock, (limit) }\end{array}$} \\
\hline & $2-5$ & $6-10$ & $11-15$ & $16-20$ & $>20$ & & \\
\hline 2012 & $\frac{85.7}{59.6}$ & $\frac{8.9}{20.7}$ & $\frac{5.4}{19.7}$ & - & - & $\frac{56}{193}$ & $\begin{array}{c}3.4 \pm 1.30 \\
(2-12)\end{array}$ \\
\hline 2013 & $\frac{87.5}{58.2}$ & $\frac{5.0}{10.3}$ & $\frac{5.0}{16.4}$ & - & $\frac{2.5}{15.1}$ & $\frac{40}{146}$ & $\begin{array}{c}3.6 \pm 1.00 \\
(2-22)\end{array}$ \\
\hline 2014 & $\frac{88.7}{65.6}$ & $\frac{7.6}{18.6}$ & $\frac{2.8}{9.7}$ & - & $\frac{0.9}{6.1}$ & $\frac{106}{360}$ & $\begin{array}{c}3.4 \pm 0.20 \\
(2-22)\end{array}$ \\
\hline 2015 & $\frac{96.2}{88.1}$ & $\frac{3.8}{11.9}$ & - & - & - & $\frac{53}{134}$ & $\begin{array}{c}2.5 \pm 0.75 \\
(2-9)\end{array}$ \\
\hline 2016 & $\frac{86.7}{58.3}$ & $\frac{9.3}{18.8}$ & $\frac{2.7}{9.1}$ & - & $\frac{1.3}{13.8}$ & $\frac{75}{276}$ & $\begin{array}{c}3.7 \pm 0.75 \\
(2-38)\end{array}$ \\
\hline 2017 & $\frac{94.5}{79.1}$ & $\frac{2.7}{7.4}$ & $\frac{1.4}{5.6}$ & $\frac{1.4}{7.9}$ & - & $\frac{74}{215}$ & $\begin{array}{c}2.9 \pm 0.20 \\
(2-17)\end{array}$ \\
\hline Total & $\frac{89.9}{66.8}$ & $\frac{6.4}{15.6}$ & $\frac{2.7}{10.1}$ & $\frac{0.3}{1.3}$ & $\frac{0.7}{6.2}$ & $\frac{404}{1324}$ & $\begin{array}{c}3.2 \pm 0.15 \\
(2-38)\end{array}$ \\
\hline
\end{tabular}

The most numerous migrants this species were in small flocks $-2-5$ individuals (in average $89.9 \%$ of all counted birds in flocks). A small number of flocks with more than 5 birds were observed, and only a few flocks contained more than 20 individuals. A total of 404 flocks of the Dunnock were registered, in which 1324 birds counted. There were from 2 to 38 individuals in one flock, on average $-3.2 \pm 0.15$ individuals (Table 2 ).

Visible migrations of birds were analysed according to observation hours during the light part of a day, altitude and flight directions. Without knowledge of these peculiarities [16], it is not possible to plan and implement measures the management for the protection of migratory birds.

Dynamics of the number of the Dunnock counted for the autumn passage in 2012-2017 is shown on Fig. 1.

The flight of this species was observed from the middle of the 1st decade of September (only solitary birds flew) to the end of the 2nd decade of October, and the main passage lasted from the 2 nd decade of September to the middle of the 2 nd decade of October. The greatest intensity of its flight was in the 3rd decade of September - 1st decade of October (Fig. 1). These flight times of the Dunnock are generally similar to those obtained in other regions of Ukraine $[1,13]$ and slightly different (earlier) than in the south, as in Hungary in particular [6].

The main influence on the intensity of migration birds had air temperature and precipitation, less - power and direction of the wind. In particular, the increase in the number of migratory these birds coincided with max- imum increase the air temperature mainly (September 2012, September-October 2015, partly in October 2013 and 2016) and with a sharp drop in the air temperature sometimes below $+5{ }^{\circ} \mathrm{C}$ (October 2012 and 2017). Passage of the Dunnock not observed during strong winds (more then $7-8 \mathrm{~m} / \mathrm{sec}$ ) and heavy rainfall.

Dynamics of passage during light part of a day is one of the most important characteristics of bird migration (Table 3).

The Dunnock is nocturnal migrant. The peak of its migrations occurs on the last night hours before sunrise [7]. In the early morning hours, these birds complete the night flight [1]. Therefore, during the visible autumn migrations, majority of them flew in the morning, in the first 3 hours of observations $(75.5-83.5 \%$ of all counted birds in different years, in average $79.6 \%$ ). Most birds flew for the second hour of observations (Table 3). A small number of there birds flew in other hours of observations.

Bird flight altitude is one of the important characteristics of bird migration also (Table 4).

As can be seen from table 4, prevalent majority of species flew at altitudes of 31-40 m (44.2-82.1\% of all counted birds in different years, average $59.4 \%$ ). Migratory birds were flying at higher altitudes when accompanying and cross winds prevailed. Some migratory birds flew at altitude where species could not be identified. Therefore, their total number was usually greater than the number of birds counted, as indicated by other researches [16].

Bird flight directions are one of the important characteristics of bird migration also (Table 5). 


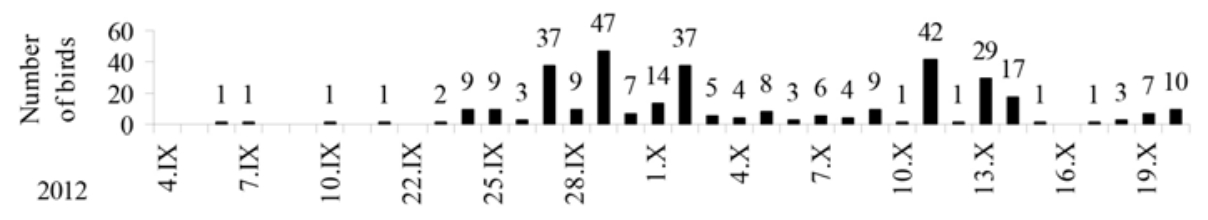

2012

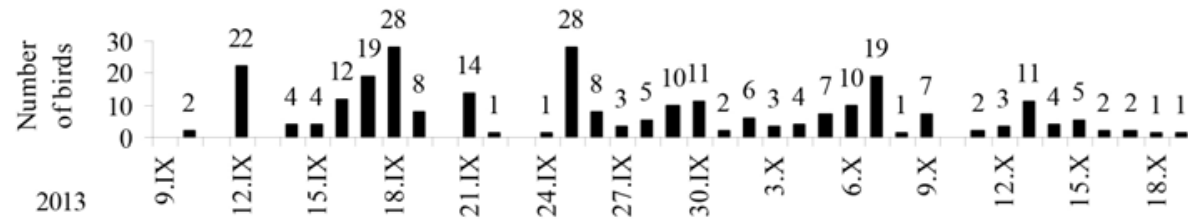

\section{3}

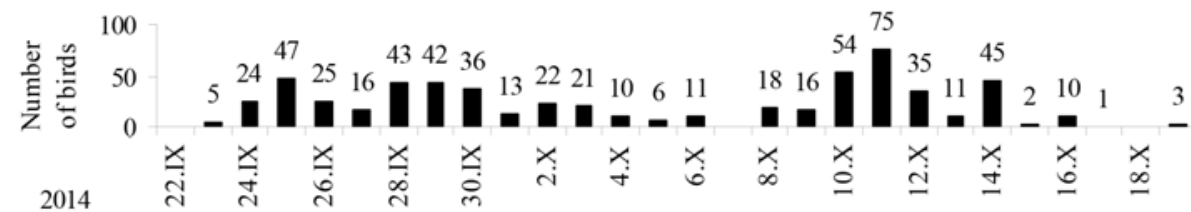

2014

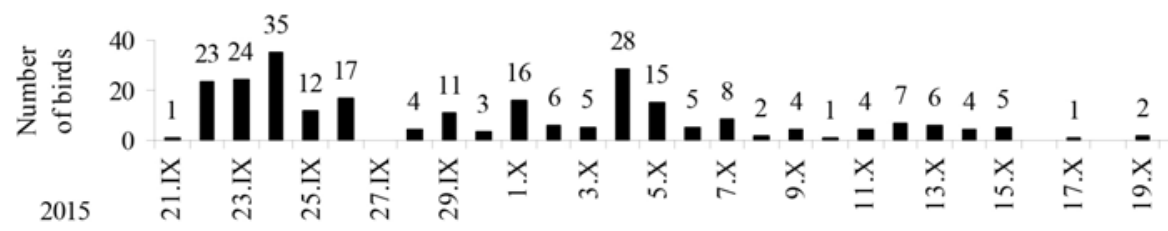

2015

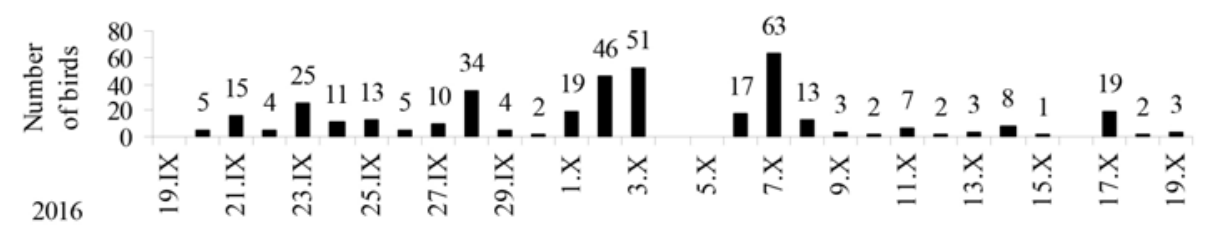

2016

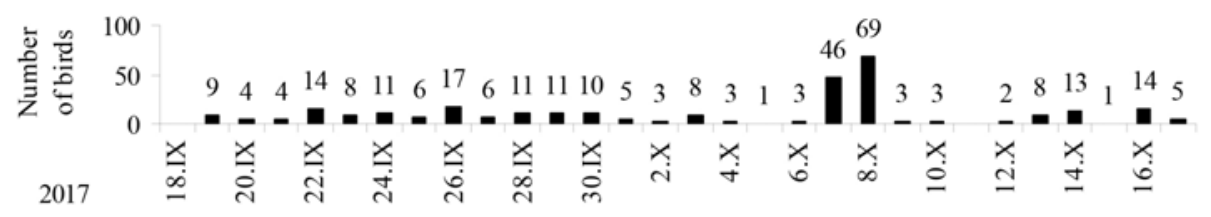

2017

Fig. 1. Dynamics of the number of Dunnocks on the autumn passage in 2012-2017

Table 3

Dynamics on passage of the Dunnock during light part of a day in autumn 2012-2017

\begin{tabular}{|c|c|c|c|c|c|c|c|c|c|c|c|c|c|}
\hline \multirow[t]{2}{*}{ Year } & \multicolumn{13}{|c|}{$\begin{array}{l}\text { Total number of birds (\%) that flew during one observation hours } \\
\text { (morning and day }- \text { No. } 1-11 \text {, evening }- \text { No. } 2-1 \text { ) }\end{array}$} \\
\hline & 1 & 2 & 3 & 4 & 5 & 6 & 7 & 8 & 9 & 10 & 11 & 2 & 1 \\
\hline 2012 & 29.8 & 35.0 & 14.9 & 8.5 & 7.6 & 3.0 & 0.6 & 0.3 & 0.3 & - & - & - & - \\
\hline 2013 & 19.6 & 32.2 & 26.3 & 10.0 & 9.3 & 2.2 & 0.4 & - & - & - & - & - & - \\
\hline 2014 & 20.8 & 34.0 & 26.2 & 13.0 & 3.9 & 1.9 & - & - & - & - & 0.2 & - & - \\
\hline 2015 & 25.3 & 34.1 & 16.1 & 9.2 & 11.7 & 3.6 & - & - & - & - & - & - & - \\
\hline 2016 & 30.5 & 24.8 & 22.7 & 8.0 & 11.9 & 1.3 & 0.8 & - & - & - & - & - & - \\
\hline 2017 & 32.9 & 36.9 & 13.7 & 10.1 & 3.7 & 2.0 & 0.7 & - & - & - & - & - & - \\
\hline Total & 26.0 & 32.7 & 20.9 & 10.2 & 7.5 & 2.2 & 0.4 & $<0.1$ & $<0.1$ & - & $<0.1$ & - & - \\
\hline
\end{tabular}


Table 4

Altitude distribution of migratory Dunnocks in autumn 2012-2017

\begin{tabular}{|c|c|c|c|c|c|c|}
\hline \multirow{2}{*}{ Year } & \multicolumn{7}{|c|}{ Height of the passage (\%) } \\
\cline { 2 - 7 } & $1-10 \mathrm{~m}$ & $11-20 \mathrm{~m}$ & $21-30 \mathrm{~m}$ & $31-40 \mathrm{~m}$ & $41-50 \mathrm{~m}$ & $>50 \mathrm{~m}$ \\
\hline 2012 & - & - & 4.2 & 82.1 & 12.2 & 1.5 \\
\hline 2013 & - & - & 8.9 & 55.5 & 22.6 & 13.0 \\
\hline 2014 & - & 1.7 & 34.7 & 61.6 & 2.0 & - \\
\hline 2015 & 3.6 & 11.3 & 25.3 & 44.2 & 9.2 & 6.4 \\
\hline 2016 & - & - & 20.4 & 59.7 & 18.9 & 1.0 \\
\hline 2017 & - & - & 20.8 & 46.0 & 26.2 & 7.0 \\
\hline Total & 0.4 & 1.8 & 21.1 & 59.4 & 13.5 & 3.8 \\
\hline
\end{tabular}

Table 5

General data about directions of migratory Dunnocks in autumn 2012-2017

\begin{tabular}{|c|c|c|c|c|c|}
\hline \multirow{2}{*}{ Species } & \multicolumn{5}{|c|}{ Direction of the passage (\%) } \\
\cline { 2 - 6 } & W & SW & S & SE & E \\
\hline 2012 & 72.9 & 27.1 & - & - & - \\
\hline 2013 & 18.5 & 81.5 & - & - & - \\
\hline 2014 & 58.2 & 41.8 & - & - & - \\
\hline 2015 & 67.1 & 30.1 & 2.8 & - & - \\
\hline 2016 & 53.0 & 45.7 & 0.8 & 0.5 & - \\
\hline 2017 & 46.7 & 52.0 & 1.3 & - & - \\
\hline Total & 53.9 & 45.4 & 0.6 & 0.1 & \\
\hline
\end{tabular}

Almost all birds migrated between the western and south-western direction. Slightly more than half of all counted birds flew to the west (on average $53.9 \%$ ) and slightly less than half - to the southwest (on average $45.4 \%$ ). Although in some years most of them flew in south-western direction (2013 and 2017).

Migratory birds used the accompanying and side winds of varying strength often and headwinds sometimes, but less power.

\section{Discussion of the research results}

The visible autumn migrations of the Dunnock were first studied in the park and have certain features. Long-term study of bird migrations (2012-2017) allowed to more objectively and exactly to determine the peculiarities of their migrations, which is important for understanding natural processes, planning and implementing measures to protect migratory routes.

According to our observations of migrations during daylight hours made it possible to establish the intensity, altitude and direction of flight. In particular, it was found that most of these birds flew in the morning, in the first three hours of observations, which is similar to the results of other researchers [1,7]. But the species is mainly a nocturnal migrant and most birds fly before sunrise, which can be determined using other research methods only [6]. Therefore, our studies did not give a complete picture of the migration of the species, particularly at night. The total number of the Dunnock can be from several times to several tens of times greater. The most birds migrated in flocks $(62.3 \%$ of all counted birds), but a significant part of them flew alone. Most of these birds flew at altitudes between 30 and $40 \mathrm{~m}$ in National Park "Prypiat-Stokhid", and in the Ukrainian Carpathians the flight of their passage is slightly lower [13]. The period of the main autumn flight of the species in the
National Park is similar in other areas of Ukraine $[1,13]$ and partly in Hungary $[6,8]$.

Study limitations. The study of visible migrations of birds requires a lot of time. One observer cannot cover a longer period of study (both light and dark part of a day) throughout the fall and spring and over large areas. Therefore, the full picture of the migrating Dunnock has not been fully studied.

Prospects for further research. The study of the visible autumn migrations of the Dunnock contributed to the addition of data on this little-studied species in Ukraine. The materials of our research are the basis for further study of visible autumn migrations of this species, possibly with a combination of other research methods and the preparation of recommendations for the protection of migratory routes of birds in general.

\section{Conclusions}

1. The peculiarities of visible autumn migrations of the Dunnock have been clarified generally: majority of them flew in the morning, in the first 3 hours of observations $(79.6 \%$ of all counted birds), within altitudes between 30 and $40 \mathrm{~m}(59.4 \%)$ and the predominant direction of flight were W (53.9\%) and some less - SW.

2. 270-591 individuals of these birds were counted during visible autumn migrations in different years, and since this species is mainly a nocturnal migrant, its total number can be from several times to several tens of times greater.

The most birds migrated in flocks, but a significant part of them flew alone. There were from 2 to 38 individuals in one flock, on average $-3.2 \pm 0.15$ individuals.

3 . The main passage lasted from the 2 nd decade of September to the middle of the 2nd decade of October.

The results of our research are the basis for the further study of this species, planning and implementation of 
conservation measures for birds in the National Park "Prypiat-Stokhid". The obtained data are also a supplement to the state of study of this species in Ukraine.

\section{Conflicts of interest}

The authors declare that they have no conflicts of interest.

\section{References}

1. Poluda, A. M. (Ed.) (2018). Tynivka lisova Prunella modularis (Linnaeus, 1758). Entsyklopediia mihruiuchykh vydiv dykykh tvaryn Ukrainy. Kyiv, 511-512.

2. Khymyn, M. (2014). Kharakterystyka vydymykh osinnikh mihratsii bilia s. Svalovychi (NPP "Prypiat-Stokhid") u 2012 2013 rr. Naukovyi visnyk natsionalnoho pryrodnoho parku "Prypiat-Stokhid", 4 (1), 40-46.

3. Khymyn, M. (2017). Kharakterystyka vydymykh osinnikh mihratsii bilia s. Svalovychi (NPP "Prypiat-Stokhid") u 2017 r. Naukovyi visnyk natsionalnoho pryrodnoho parku "Prypiat-Stokhid", 7 (2), 19-38.

4. Ilchuk, V. P. (2015). Materialy po fenolohii mihratsii ptakhiv u pivdennii chastyni Rivnenskoi oblasti. Avifauna Ukrainy. Dodatok do zhurnalu "Berkut", 6, 66-72.

5. Redinov, K. O. (2016). Materialy po fenolohii mihratsii ptakhiv na zakhodi Mykolaivskoi oblasti. Avifauna Ukrainy. Dodatok do zhurnalu "Berkut", 7, 69-77.

6. Csörgo, T., Móra, V., Miklay, G. (2001). Autumn migration and wintering of Dunnock (Prunella modularis) in Hungary. The Ring, 23 (1-2), 99-107.

7. Michalik, B., Brust, V., Hüppop, O. (2020). Are movements of daytime and nighttime passerine migrants as different as day and night? Ecology and Evolution, 10 (20), 11031-11042. doi: http://doi.org/10.1002/ece3.6704

8. Harnos, A., Fehérvári, P., Piross, I. S., Ágh, N., Karcza, Z., Konrád, K., Csörgö, T. (2016). Exploratory analyses of migration timing and morphometrics of the Dunnock (Prunella modularis). Ornis Hungarica, 24 (2), 127-144. doi: http://doi.org/10.1515/orhu-2016-0020

9. Menzie, S., Malmhagen, B. (2013). Ageing DunnocksPrunella modularisusing plumage characteristics. Ringing \& Migration, 28 (1), 57-62. doi: http://doi.org/10.1080/03078698.2013.811166

10. Zaniewicz, G., Busse, P. (2008). Autumn Migration Dynamics and Biometrical Differentiation of the Dunnock (Prunella modularis) Passing the Southern Baltic Coast. Ring, 30 (1-2), 31-54. doi: http://doi.org/10.2478/v10050-008-0006-1

11. Hüppop, O., Dierschke, J., Exo, K-M., Fredrich, E., Hill, R. (2006). Bird migration studies and potential collision risk with offshore wind turbines. Ibis, 148, 90-109. doi: http://doi.org/10.1111/j.1474-919x.2006.00536.x

12. Rydell, J., Engström, H., Hedenström, A., Larsen, J. K., Pettersson, J., Green, M. (2012). The effect of wind power in birds and bats - a synthesis. Report 6511. Stockholm: Swedish Environmental Protection Agency, 150.

13. Dubovyk, O., Bokotey, A., Pokrytiuk, L., Bodnar, V., Strus, Yu., Ruchko, O. (2020). Autumn migration of birds over Polonyna Borzhava (Ukrainian Carpathians). Zoodiversity, 54 (1), 43-52. doi: http://doi.org/10.15407/zoo2020.01.043

14. Ilieva, M., Bianco, G., Åkesson, S. (2018). Effect of geomagnetic field on migratory activity in a diurnal passerine migrant, the dunnock, Prunella modularis. Animal Behaviour, 146, 79-85. doi: http://doi.org/10.1016/j.anbehav.2018.10.007

15. Kumari, E. (1979). Metodika izucheniia vidimykh migratsii ptits. Tartu, 59

16. Poluda, A. M. (1992). Obschaia kharakteristika vidimykh migratsii ptits v raione Kievskogo vodokhranilischa. Sezonnye migratsii ptits na territorii Ukrainy. Kyiv: Naukova dumka, 24-53.

17. Khymyn, M. (2014). Kharakterystyka vydymykh osinnikh mihratsii bilia s. Svalovychi (NPP "Prypiat-Stokhid") u 2014 r. Naukovyi visnyk natsionalnoho pryrodnoho parku "Prypiat-Stokhid", 4 (2), $43-55$.

18. Khymyn, M. (2015). Kharakterystyka vydymykh osinnikh mihratsii bilia s. Svalovychi (NPP "Prypiat-Stokhid") u 2015 r. Naukovyi visnyk natsionalnoho pryrodnoho parku "Prypiat-Stokhid", 5 (2), 19-41.

19. Khymyn, M. (2017). Kharakterystyka vydymykh osinnikh mihratsii bilia s. Svalovychi (NPP "Prypiat-Stokhid") u 2016 r. Naukovyi visnyk natsionalnoho pryrodnoho parku "Prypiat-Stokhid", 7 (1), 31-49.

20. Lakin, G. F. (1980). Biometriia. Moscow: Vysshaia shkola, 293.

21. Meklenburtsev, R. N. (1954). Semeistvo Prunellidae. Ptitsy Sovetskogo Soiuza. Moscow: Sovetskaia nauka, VI, 624 660.

Received date 10.11.2020

Accepted date 21.12.2020

Published date 30.12.2020

Mykhailo Khymyn, Deputy Director for Research, National Park "Prypiat-Stokhid", Bondarenko str., 47, Liubeshiv settlement, Volyn region, Ukraine, 44200

E-mail: michaelkhymyn@ukr.net 